\title{
Inducement grants, hiring announcements, and adverse selection for new CEOs
}

\section{Brian Cadman ${ }^{1}$ (D) $\cdot$ Richard Carrizosa ${ }^{2} \cdot$ Xiaoxia Peng $^{1}$}

Published online: 16 November 2019

(C) The Author(s) 2019, corrected publication 2021

\begin{abstract}
We examine how adverse selection problems when hiring new external CEOs affect contractual features of inducement grants. Focusing on the sensitivity of inducement grants to the new CEO announcement return (\$Sensitivity), we find that firms provide inducement grants that are more sensitive to the new CEO announcement return when information asymmetry about the new CEO is more severe and the costs of adverse selection problems are higher. We also find a positive relation between the market reaction to the appointment and \$Sensitivity. We consider factors that reduce information asymmetry (e.g., engaging a search firm or appointing internal CEOs) and find they are associated with lower sensitivity of the inducement grant to the announcement.
\end{abstract}

Keywords Inducement grants · CEO turnover · Adverse selection

JEL Classification J33 · M12 · M52

\section{Introduction}

Selecting a new CEO is one of the most important tasks facing a firm's board of directors (Hermalin 2005; Adams et al. 2010). The task is difficult because the board has

\author{
Brian Cadman \\ brian.cadman@eccles.utah.edu \\ Richard Carrizosa \\ rdcarrizosa@utep.edu \\ Xiaoxia Peng \\ xiaoxia.peng@eccles.utah.edu
}

1 David Eccles School of Business, University of Utah, 1655 E Campus Center Dr., Salt Lake City, UT 84112, USA

2 College of Business Administration, University of Texas at El Paso, 500 W. University Ave., El Paso, TX 79902, USA 
limited information about the potential CEO. The information asymmetry between the board and the CEO is particularly severe when a firm hires a new external CEO. Despite the additional agency costs, firms often hire CEOs from the outside (Murphy and Zabojnik 2004). One mechanism to resolve these agency problems is through features of the initial contract. Prior studies document that firms provide inducement grants (also known as sign-on bonuses) that include cash and equity to mitigate termination risk (Xu and Yang 2016) and to compensate CEOs for wealth they forgo at their prior institution (Fee and Hadlock 2003). We extend the literature to investigate how firms utilize sign-on grants to help reduce adverse selection problems.

When a firm hires an external CEO, there is limited information about the new CEO's skills and aversion to risk. Adverse selection may exist because of the CEOs' tendency to withhold private negative information and their inability to credibly disclose private information about their skills and aversion to risk. As a result, CEOs with skills and aversion to risk that do not meet the needs of the firm pool with those that do to earn the job. One way that firms can reduce adverse selection problems is by exposing the value of the inducement grant to the new CEO announcement return.

The new CEO announcement return reflects the market's expectation of the CEO's effect on firm value, where some investors have private information about the incoming CEO that is not known by the board and only becomes valuable after the new CEO announcement. The sensitivity of the inducement grant to the new CEO announcement return may help firms mitigate adverse selection problems on at least two dimensions. First, by imposing risk on the CEO, inducement grants that are more sensitive to the new CEO announcement return help firms select CEOs who are less averse to risk. Second, inducement grants that are sensitive to the new CEO announcement return help firms resolve adverse selection problems about CEO skill because investors' private information is revealed in the new CEO announcement return. CEOs that cannot credibly disclose private information about their skills and expect the market to react favorably to the announcement return are willing to accept inducement grants that are more sensitive to the announcement return.

Inducement equity grants are determined before the new CEO announcement. The sensitivity of the inducement grant to the new CEO announcement return is related to the amount, type, and timing of equity granted. ${ }^{1}$ While the magnitude of the equity grant helps resolve adverse selection and moral hazard problems, the sensitivity of the inducement grant to the new CEO announcement is a contract feature that is an effective mechanism to address adverse selection problems. This measure differs from other measures of incentives provided to new CEOs, such as the delta of annual equity grants, because it isolates the contract feature that is insulated from CEO effort and is a distinct construct from that of prior studies on the magnitude of inducement grants (e.g., Fee and Hadlock 2003; Xu and Yang 2016). Some firms grant equities where the value of the equity is sensitive to the announcement return, while other firms provide inducement equity awards with values that are not exposed to the announcement return.

\footnotetext{
${ }^{1}$ Only the equity portion of the inducement grant can be sensitive to the announcement return.
} 
Firms must weigh the benefits of resolving adverse selection problems against the cost of imposing additional risk on the CEO. We first predict that the sensitivity of inducement grants to the new CEO announcement return increases in information asymmetry about the CEO. We also hypothesize that firms contract with inducement grants that are more sensitive to the announcement return to select CEOs that are less averse to risk when the potential losses from underinvestment in risky projects are greater. Finally, we predict that firms contract with inducement grants that are more sensitive to the announcement return to resolve adverse selection problems when the costs of identifying and replacing a less productive CEO are more severe. Together, we predict that firms increase the CEO's exposure to the announcement return when the benefit of resolving the adverse selection problems is greater, while firms that are less concerned about adverse selection problems may resolve moral hazard problems efficiently by granting equities that are not sensitive to the announcement return.

We test these predictions in a sample of 510 new CEOs that were hired from outside the firm between 2004 and 2013. We identify the initial contract information from $8-\mathrm{K}$ filings and measure the sensitivity of the inducement grant to the new CEO announcement return as the change in value of the inducement grant to a one percent announcement return. The sensitivity of each grant is a function of whether the grant date is before or after the CEO announcement, whether the grant is a stock or option grant, and whether it is contracted on the number of shares or a fixed value. \$Sensitivity Grant is calculated as the change in the pre-announcement grant value for a one percent change in stock price using pre-announcement stock prices and other valuation inputs. We aggregate \$Sensitivity Grant for each element of the inducement grant to measure the sensitivity of the total inducement grant, \$Sensitivity.

We measure information asymmetry about the CEO using the change in stock return volatility around the new CEO announcement following Neuhierl et al. (2013). Prior research shows that the change in stock return volatility following news announcements reflects uncertainty about the news, and that the change in stock return volatility is positively related to uncertainty about the new CEO (Clayton et al. 2005; Neuhierl et al. 2013). To measure the benefits of identifying a CEO that is less averse to risk, we use the investment opportunity set $(I O S)$ to capture the potential loss from underinvestment in valuable risky projects, as in Baber et al. (1996) and Gaver and Gaver (1993). To measure the costs of identifying and replacing a less productive $\mathrm{CEO}$, we use the homogeneity of the industry in which the firm operates, following Parrino (1997), who suggests that firms in more homogeneous industries can more easily determine CEO skills ex post and face lower costs to replace CEOs.

In support of our prediction about information asymmetry and contractual features to mitigate adverse selection problems, we find that the sensitivity of inducement equity awards to the new CEO announcement return increases in information asymmetry about the CEO. Consistent with firms that face greater costs from not resolving adverse selection problems being more willing to bear the cost of imposing additional risk on the new CEO, we find that firms with greater potential losses from underinvestment in valuable risky projects and firms facing greater costs of identifying and replacing a less productive CEO contract with inducement grants that are more sensitive to the announcement return. 
We conduct tests to validate our assumption that CEOs who expect the market to respond favorably to the announcement of their appointment accept inducement grants that are more sensitive to the announcement return. Specifically, we document a positive relation between the stock market reaction to the new CEO announcement and the sensitivity of inducement grants to the announcement return. We also consider whether the sensitivity of the inducement grant to the new CEO announcement return is related to the accounting and market performance of the firm over the year following the new CEO appointment. We find a positive relation between industry adjusted ROA and inducement grant sensitivity. However, we do not find long-term stock performance to be related to the contractual features, which suggests that the market impounds the expected effect of the new CEO appointment at the time of the announcement.

We consider additional factors that may inform the board about the potential CEO. First, some boards retain an executive search firm to aid in the selection of, and to reduce information asymmetry about, the CEO. Second, we consider internal CEO appointments, where the board has more information about the potential CEO through the CEO's employment with the firm. We find that firms provide inducement grants that are less sensitive to the announcement return when the board hires an executive search firm or appoints an internal CEO.

We examine two other forces that may influence contractual features. First, we consider observable CEO experience. There is less information asymmetry about CEOs with more experience, which would predict lower \$Sensitivity. At the same time, the market is more likely to respond favorably to the appointment of a CEO with more experience that is more likely to have a greater skill set, which predicts greater \$Sensitivity. We find a positive relation between $\$$ Sensitivity and a measure of observable CEO experience. We also consider whether the board has additional experience with the newly appointed CEO through overlapping employment. We find no relation between the sensitivity of the inducement grant and this measure of the board's experience with the CEO. ${ }^{2}$

In additional tests, we consider whether firms offset the risk of inducement grant sensitivity with other forms of pay. We find no evidence that firms provide additional compensation when the sensitivity of the inducement grant is higher. We also consider other forms of compensation that may complement the sensitivity of inducement grants to the announcement return to help resolve adverse selection problems. We find that annual equity grants are related to \$Sensitivity, but not in a way that influences our primary results.

We contribute to the growing stream of literature on contract design for new CEOs by focusing on how information asymmetry about the potential CEO influences contractual features (Darrough and Melumad 1995; Gillan et al. 2009; Xu and Yang 2016). We provide evidence that the sensitivity of inducement grants to the new CEO announcement return is an effective contractual feature to resolve adverse selection problems. We also provide additional insights into the design and use of inducement

\footnotetext{
${ }^{2}$ We discuss explanations for the lack of a relation in Section 4.4.3.
} 
grants documented in prior literature (Fee and Hadlock 2003; Xu and Yang 2016; and Van Wesep 2010). Our study is an important addition to prior literature that focuses on how moral hazard problems influence CEO compensation contracts (e.g., Jensen and Murphy 1990). Finally, our study is related to literature on contracting to resolve adverse selection problems in other settings, such as Houston and Ryngaert (1997), who show that the sensitivity of the value of the target's compensation to the bidder's stock price around bank mergers resolves adverse selection problems.

\section{Hypotheses development}

When an external CEO is hired, there is information asymmetry between the board and the CEO about the ability and risk-taking preferences of the new CEO. Information asymmetry exists because of the CEO's tendency to withhold private negative information and their inability to credibly disclose private information about their skills and aversion to risk. For example, CEOs cannot credibly disclose private positive information to the board, such as the role they played in the success of their prior firm. In addition, CEOs may withhold negative information from the board, such as projects that failed while they were CEOs at the prior institutions. Such asymmetric information results in adverse selection problems (Greenwald 1986). That is, because the CEO can not credibly reveal their type, aspiring CEOs with skills and aversion to risk that do not meet the needs of the firm pool with those that do to earn the job and reap the benefits of the position.

The initial contract is one place where contractual features can be employed to mitigate adverse selection problems that arise from information asymmetry about the CEO. Most newly appointed CEOs receive an inducement grant that includes cash and/or equity in the firm (Fee and Hadlock 2003; Xu and Yang 2016; Van Wesep 2010). These inducement grants may include equity grants with values that are sensitive to the market's reaction to the announcement of the new CEO appointment. Providing inducement grants with values that are sensitive to the new CEO announcement return may help resolve adverse selection problems.

The sensitivity of the inducement grant to the new CEO announcement return may help firms mitigate adverse selection problems on at least two dimensions. First, imposing risk on the $\mathrm{CEO}$ with inducement grants that are more sensitive to the new CEO announcement return helps firms select CEOs who are less averse to risk. The new CEO announcement return reflects the market's expectation of the CEO's effect on firm value, which is uncertain when the firm contracts with the new CEO. Second, inducement grants that are sensitive to the new CEO announcement return help firms resolve adverse selection problems about CEO skill. Some investors may have private information about the CEO that the CEO withholds from, or is unable to credibly disclose to, the board. Such private information only becomes valuable after the new CEO announcement, and is revealed in the announcement return (e.g., Kim and Verrecchia 1997; Lambert et al. 2007). Because the CEO expects the market to react to the announcement in a way that is consistent with the private information, the sensitivity of the inducement grant value to the new CEO announcement return helps 
firms resolve adverse selection problems about CEO skill. Therefore, the sensitivity of the inducement grant to the new CEO announcement return can help resolve adverse selection problems by creating a separating equilibrium where CEOs that are less averse to risk, or that expect the market to respond favorably to their appointments are more willing to accept inducement grants with greater sensitivity to the announcement return.

Despite the benefits of resolving adverse selection problems, there are costs to these contractual features. Specifically, inducement grants that are exposed to the announcement return impose risk on the CEO, which increases the cost of contracting. The firm's willingness to bear the contracting cost increases with the benefits of resolving the adverse selection problem.

The benefits from contractual features to mitigate adverse selection problems increase with information asymmetry about the CEO. Therefore, we predict that firms contract with inducement grants that are more sensitive to the new CEO announcement return as information asymmetry about the CEO increases. This leads to our first hypothesis:

\section{H1: Inducement grant sensitivity to the new CEO announcement return increases in information asymmetry about an incoming $C E O$.}

Given the level of information asymmetry about the CEO, the costs of adverse selection problems vary across firms. Firms with more risky investment opportunities require a CEO with a greater appetite for risk to exploit those opportunities. A CEO that is more risk averse may underinvest in risky projects. Baber et al. (1996) and Guay (1999) predict and find that firms contract to limit the potential loss from underinvestment in risky projects. We predict that firms contract with inducement grants that are more sensitive to the announcement return as the potential loss from underinvestment in valuable risky projects increases. This leads to our second hypothesis: ${ }^{3}$

\section{H2: Inducement grant sensitivity to the new CEO announcement return} increases in the firm's potential losses from underinvestment in valuable risky projects.

The cost of correcting the adverse selection problem ex post also varies. Specifically, the cost of identifying and replacing a less productive CEO varies with industry factors and labor market conditions. When the cost of correcting the adverse selection problem ex post is greater, we expect that firms are more willing to bear the additional cost of contracting with inducement grants that are sensitive to the announcement return. This leads to our third hypothesis:

H3: Inducement grant sensitivity to the new CEO announcement return increases in the cost of identifying and replacing a less productive CEO.

\footnotetext{
${ }^{3}$ This hypothesis does not require the market to be more informed than the board about the CEO.
} 


\section{Sample and empirical methodology}

\subsection{Sample}

To construct a comprehensive sample of new external CEO hirings, we use reports that the Securities and Exchange Commission (SEC) requires firms to file when appointing new executives. The SEC requires newly appointed officers to file an initial statement of beneficial ownership of securities (Form 3) within 10 days of appointment. We start with the entire set of Form 3s in EDGAR (Electronic Data Gathering, Analysis, and Retrieval system of the SEC) filed after January 1, 2004, and search the titles of reporting persons to identify filings associated with new CEO appointments. ${ }^{4}$ In addition, since August 23, 2004, companies have been required to file a Form 8-K (Item 5.02) within four business days of a new CEO appointment and to describe, in the filing, any contract or arrangement associated with the event. We then match each new CEO Form 3 to all 8-Ks (with Item 5.02 events) that are filed within 90 days before or after the Form 3 filing date, and examine each filing to identify which 8-K includes the new CEO announcement. We retain all observations for which we are able to match a Form 3 to the corresponding new CEO announcement $8-\mathrm{K}$. To identify the new CEO announcement date, we record the press release date from the $8-\mathrm{K}$ filing if available, or by searching Factiva.

To measure contract details, we inspect the 8-K for initial contract information. NASDAQ Listing Rule 5635(c) and NYSE rule 303A.08 require that a listed company seek shareholder approval when it establishes or materially amends a stock option, stock purchase plan, or other stock-based compensation for officers, directors, employees, or consultants. However, the listing rules also indicate that shareholder approval is not required for an issuance to a person not previously an employee or director of the company as an inducement to enter into employment with the company. ${ }^{5}$ Although shareholder approval is not required, the company must issue a press release that discloses the material terms of inducement awards promptly following the contract signing. To satisfy the listing requirements, firms generally disclose details about inducement grants with the new CEO announcement. We record inducement grants from contracts that are included as exhibits to the $8-\mathrm{K}$ filings that contain the CEO announcements. When a contract is not included as an exhibit, we search the body of the $8-\mathrm{K}$ and the press release for the contract details. We retain all new external CEO appointments with the necessary data to conduct our tests.

We take several additional steps to ensure the accuracy of the measures in our sample. First, we use SDC Platinum M\&A data to exclude new CEO appointments associated with mergers. Also, to ensure that our sample of external CEO

\footnotetext{
${ }^{4}$ We search the reported title in the Form 3 for terms similar to "Chief Executive" and "CEO" to identify filings linked to new CEOs. We exclude division CEOs.

${ }^{5}$ Because inducement equity grants do not require shareholder approval, there are concerns that inducement grants, which increase dilution, may be used by companies to bypass corporate governance. These concerns are mitigated by the fact that advisory firms consider the dilutive effects of inducement equity grants when making recommendations for equity plans in the future (ISS, 2016).
} 
appointments includes only external CEOs and not individuals who were promoted from within the company, we exclude any observations for which the initial holdings reported in Form 3 are greater than 5\% of the number of underlying securities in the inducement grants. Our final sample consists of 510 new external CEO appointments where we can observe the initial contract, CEO characteristics, and hiring firm characteristics and have sufficient data to construct the CEO announcement return and control variables.

\subsection{Inducement grant sensitivity to the announcement return}

Inducement grants often include cash and equity. While cash is not sensitive to the announcement return, equity grants may be. The amount of an equity grant is specified using either a fixed dollar value or a fixed number of securities. Although inducement grant contract terms are determined before the announcement, there is variation in equity grant dates relative to the new CEO announcement. Specifically, some firms contract with inducement equity awards that are granted before the new CEO announcement. Other inducement grants include equity awards of a fixed number of securities that are determined prior to the new CEO announcement but granted after the announcement. Both of these granting patterns expose the value of the equity awards to the announcement return. In contrast, some firms contract with inducement equity awards of a predetermined value that are granted after the new CEO announcement, which shields the value of the equity grant from the announcement return.

We measure the sensitivity of the inducement grant to the new CEO announcement return as the change in value of the inducement grant for a one percent change in the stock price. The sensitivity of each grant, \$Sensitivity Grant, is determined by its specific design features, including whether the grant date is before or after the CEO announcement, whether the grant is a stock grant or an option grant, and whether it is contracted on the number of shares or a fixed value. To measure \$Sensitivity Grant, we estimate pre-announcement grant values using pre-announcement stock prices and other valuation inputs, and quantify the changes in grant values that result from a one percent change in stock price.

To illustrate the method used to measure the grant sensitivity, consider a contract that is finalized two days prior to the CEO announcement and includes the following four inducement equity grant types:

1. Post Stock $\$$ : stock with a total value of $\$ 50,000$, granted the day after the new CEO announcement;

2. Pre Stock \#: 500 shares of stock granted two days prior to the new CEO announcement;

3. Post Option \#: 1,000 stock options granted the day after the new CEO announcement;

4. Pre Option \#: 1,000 stock options granted two days prior to the new CEO announcement.

Assume a stock price that equals $\$ 100$ two days prior to the announcement and an announcement return that is one percent $(\$ 1)$. Also, assume that options are granted 
with an exercise price that is equal to the stock price of the underlying security on the grant date, and the parameters to determine the stock option values include stock volatility of 0.3 , time to expiration of seven years, dividend yield of zero, and a riskfree rate of $10 \%$. Also, assume that, other than stock price, the input parameters are constant over the new CEO announcement period.

Because the value of Post Stock $\$$ is unaffected by changes in stock price around the CEO announcement, the sensitivity of Post Stock $\$$ is zero. After the announcement, the firm issues 495.05 shares to meet the contracted $\$ 50,000$. In contrast, Pre Stock \# is sensitive to the announcement return. The one percent announcement return increases the value of Pre Stock \# from \$50,000 to \$50,500, a sensitivity of \$500 (or one percent).

Although Post Option \# consists of options with the number of securities underlying the option set prior to the announcement, it is granted after the announcement and thus its value is sensitive to the announcement return. To estimate the sensitivity of Post Option \#, we first estimate the pre-announcement value of the options using the pre-announcement stock price and option pricing inputs. Although the value of Post Option \# is not determined until the strike price is set following the announcement, the value of an equivalent grant with a strike price equal to the preannouncement stock price is the benchmark for measuring the sensitivity of Post Option \# to the announcement return. In this example, the stock price prior to the announcement of $\$ 100$, along with the parameter assumptions, results in an estimated value of $\$ 60,866.86$ for the 1,000 stock options in Post Option \#. An announcement return of one percent would cause the exercise price of the actual grant to increase by one percent, and assuming all other inputs remain constant, the value of Post Option \# would be $\$ 61,476.53$ after the announcement. Therefore the sensitivity of Post Option \# to a one percent announcement return is the difference between the postannouncement value of $\$ 61,476.53$ and the pre-announcement value of $\$ 60,866.86$, which is $\$ 608.67$.

The value of Pre Option \#, which includes options granted prior to the new CEO announcement, is $\$ 60,866.86$. The sensitivity of the option value to a one percent change in stock price is $\$ 883.09$, which is one percent $* \$ 100$ (the stock price) * 0.88309 (the option delta) * 1,000 (the number of options). In Appendix A, we provide sensitivity calculations for all inducement grant types.

These examples demonstrate that \$Sensitivity Grant varies substantially with contract terms and is a distinct construct that captures the degree to which the inducement grant is exposed to the announcement return. As an example of the distinct qualities of \$Sensitivity Grant, note that an equity grant that is contracted to occur in the future, e.g., Post Option \#, is sensitive to the return on the underlying security after the contract date but before the grant occurs. \$Sensitivity Grant is also different from other measures of incentives such as the delta of the stock and option grants of the annual contract, because \$Sensitivity Grant captures the sensitivity to the new CEO announcement return, which is insulated from CEO effort. Therefore, while there may be economic reasons for granting equity to new CEOs to help resolve moral hazard problems, \$Sensitivity Grant isolates the contract feature that is sensitive to the new CEO announcement return and not affected by CEO effort. Because many firms provide inducement grant portfolios that consist of multiple 
equity grants, we aggregate the sensitivity of the inducement equity grants, \$Sensitivity Grant, for a new CEO to calculate the total sensitivity to the announcement return, \$Sensitivity.

\subsection{Research design}

Uncertainty about the ability and risk-taking preferences of the new CEO increases volatility following the hiring announcement. We measure Information Asymmetry as the change in stock return volatility in response to the new CEO announcement between the event window (event days 0 and 1) and pre-event window (event day -1), where day 0 is the new CEO announcement date. Stock prices are sampled at fiveminute intervals using intra-day data from the Trading and Quotes (TAQ) database and the midpoints of bid-ask spreads. ${ }^{6}$ Neuhierl et al. (2013) show that changes in volatility capture the valuation uncertainty content of news, which we extend to the market's uncertainty about the CEO. Similarly, Clayton et al. (2005) find that stock return volatilities increase more for external CEO appointments that are more uncertain. We measure the uncertainty over the short window around the new CEO announcement in order to capture information asymmetry about the CEO when the news is disclosed. This is a proxy for information asymmetry between the board and the CEO before the board takes actions to reduce the information asymmetry. We consider these actions in Section 4.4.

To capture the potential loss from underinvestment in valuable risky projects, we follow Baber et al. (1996) and Gaver and Gaver (1993) and measure the investment opportunity set $(I O S)$. IOS is a factor score that represents the investment opportunity set based on investment intensity, market-to-book value of assets, geometric mean annual growth rate of the market value of assets, and R\&D expenditures scaled by assets. As evidence that this measure captures the investment opportunity set, Baber et al. (1996) show that IOS is related ex post to the firm's investments, and Guay (1999) predicts and finds that firms provide incentives to take risk as a function of the potential loss from underinvestment in risky projects. ${ }^{7}$

To measure the cost of identifying and replacing a less productive CEO, we use the homogeneity of the industry in which the firm operates. Following Parrino (1997), we measure Industry Homogeneity as the average partial correlation of stock returns within an industry over the five years that precede the new CEO announcement. Parrino (1997) suggests that firms in more homogeneous industries can more easily determine CEO skills ex post and face lower costs to replace CEOs.

\footnotetext{
${ }^{6}$ We require at least 50 quotes per day and use linear interpolation between the two most recent quotes when the price for a five-minute interval is not available. We also require at least 60 data points for every event day to calculate the intra-day return volatility and the stock to have quotes for at least half of the trading day.

${ }^{7}$ It is possible that IOS captures the potential for overinvestment in risky projects, where firms with high IOS prefer a CEO that is more averse to risk. This predicts a negative relation between inducement grant sensitivity and IOS. Baber et al. (1996) and Guay (1999) find results that are not consistent with IOS capturing the potential for overinvestment in risky projects.
} 
We use these proxies to test our hypotheses by estimating the following equation:

$$
\begin{aligned}
\text { \$Sensitivity }= & \beta_{0}+\beta_{1} \text { Information Asymmetry }+\beta_{2} I O S \\
& +\beta_{3} \text { Industry Homogeneity } \\
& +\beta_{4} \text { Size }+\beta_{5} \text { Leverage }+\beta_{6} \text { Volatility } \\
& +\beta_{7} \text { Return }+\beta_{8} \text { ROA }+\Sigma_{i} \beta_{i} \text { Year }_{i}+\varepsilon
\end{aligned}
$$

Our first hypothesis predicts that the sensitivity of the inducement grant to the announcement return is increasing in information asymmetry about the $\mathrm{CEO}, \beta_{1}>$ 0 . Our second hypothesis predicts that inducement grant sensitivity to the announcement return is increasing in the potential loss from underinvestment in valuable risky projects, $\beta_{2}>0$. H3 predicts that firms facing higher costs of identifying and replacing a less productive $\mathrm{CEO}$ provide inducement grants that are more sensitive to the announcement return, $\beta_{3}<0$.

We include a set of control variables to capture other economic determinants of the sensitivity of the inducement grant to the new CEO announcement return. Equation (1) includes the logarithm of hiring firm total assets, Size, to control for the effect of firm size on total compensation levels (Murphy 1985). We also include the book value of debt divided by market value of equity, Leverage, and the daily return volatility over the 12 months prior to the new CEO announcement, Volatility, as measures of firm risk. Finally, we include accounting and market performance of the firm over the 12 months preceding the new CEO announcement to capture the relation between firm performance and the newly appointed CEO contract. $R O A$ is the net income divided by the book value of total assets over the four quarters prior to the new CEO announcement date. Return is the buy-and-hold stock return over the 12 months prior to the new CEO announcement. The model includes year fixed effects.

\section{Data and results}

\subsection{Sample distribution and summary statistics}

Our sample includes 510 new external CEO announcements from 2004 through 2013. Table 1 presents summary statistics of \$Sensitivity Grant and sample distribution by inducement grant type. To measure \$Sensitivity Grant, we use the closing stock price on the grant date, the annualized daily stock return volatility over the 12 months prior to the new CEO announcement, the dividend yield for the fiscal year prior to the new CEO appointment, a time-to-expiration of seven years, and the seven-year U.S. Treasury bill rate on the grant date.

Inducement equity grants include options or stock appreciation rights that are granted prior to the announcement with a contracted number of shares (Pre Option $\#)$ in 102 instances. The mean (median) sensitivity of this grant type is $\$ 41,630$ $(\$ 18,690)$. Inducement grants include stock with a contracted number of shares (Pre Stock \#) in 47 instances, with a mean (median) sensitivity of $\$ 17,960(\$ 8,170)$. In two cases, firms grant options with a contracted value prior to the new CEO announcement (Pre Option \$), with an average sensitivity of $\$ 82,400$. In eight cases, firms 


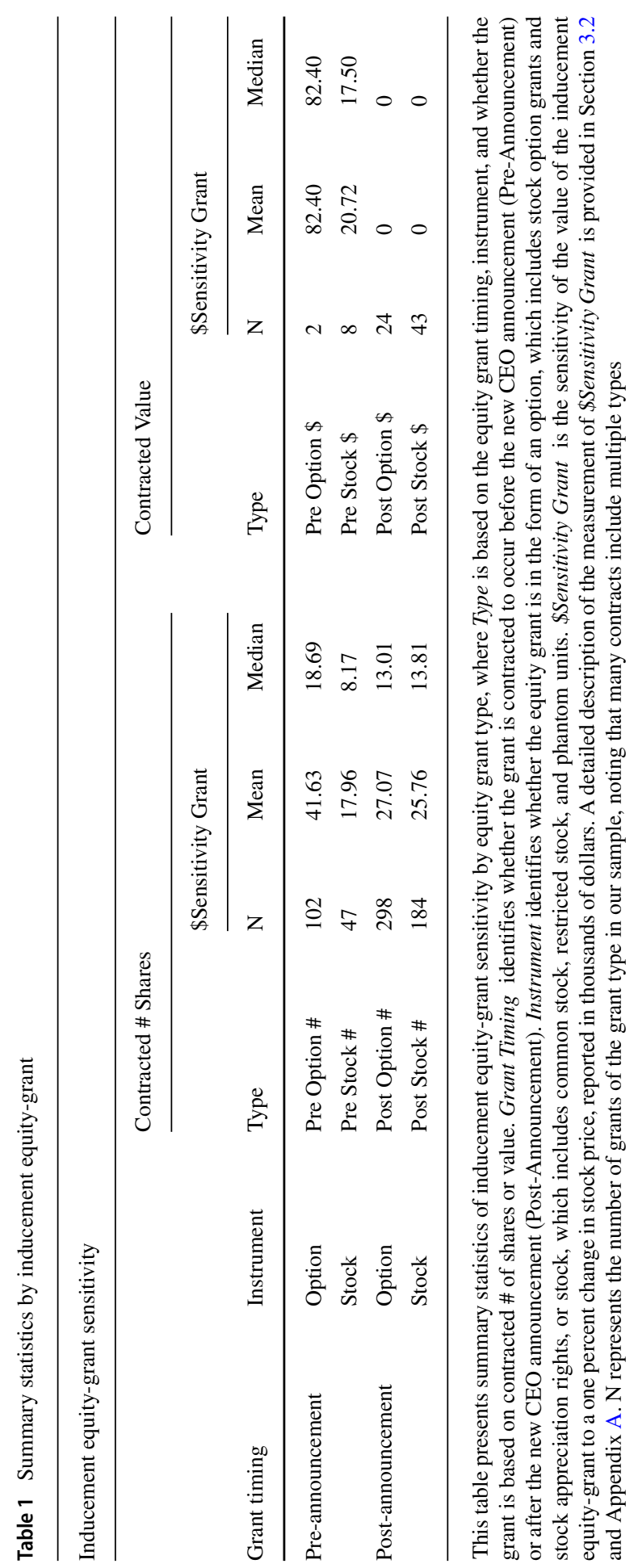


grant stock with a contracted value prior to the CEO announcement (Pre Stock \$), with a mean (median) sensitivity of $\$ 20,720(\$ 17,500)$.

Although equities granted prior to the new CEO announcement make up the greatest average sensitivity to the announcement return, equities with a contracted number of securities prior to the announcement but granted after the announcement constitute the greatest frequency of inducement grants. This set includes 298 instances of option grants (Post Option \#) and 184 instances of stock grants (Post Stock \#). The mean (median) sensitivities of these grants to a one percent announcement return are $\$ 27,070(\$ 13,010)$ and $\$ 25,760(\$ 13,810)$, respectively.

Finally, 67 grants include equities that are insulated from the announcement return. Specifically, firms grant inducement equity awards with contracted values that are granted after the CEO announcement and thus are not sensitive to the CEO announcement return, in 24 instances of stock option grants (Post Option \$) and in 43 instances of stock grants (Post Stock \$).

Together, the summary statistics provided in Table 1 illustrate the variation in inducement equity grant patterns and the influence of that variation on the sensitivity of the inducement grant to the announcement return. Because some firms provide inducement grants that consist of multiple equity grants, we aggregate the portfolio of inducement equity grants for a new CEO to calculate the total sensitivity to the announcement return, \$Sensitivity. Most firms award one or two types of grants, and the average number of grant types is 1.4 .

Table 2 presents summary statistics of initial CEO contracts, the predicted economic determinants, and other hiring firm characteristics. The proportion of our sample that includes new external CEOs with a sign-on bonus (either cash or equity) is $97 \%$, which is consistent with the proportion found by Fee and Hadlock (2003). Mean (median) sensitivity of the inducement equity grant portfolio, \$Sensitivity, is $\$ 33,450(\$ 16,030)$ for a one percent announcement return. New CEO appointments include inducement equity grants 95 percent of the time. The mean (median) value of inducement grants is $\$ 3,206,030(\$ 1,785,640)$, while the mean (median) value of cash sign-on bonus is $\$ 159,160(\$ 0){ }^{8}$ Sign-on cash bonus is $5 \%$ of total inducement grants, on average.

Turning to our hypothesized determinants of the sensitivity to the new CEO announcement return, the mean (median) Information Asymmetry is $0.11(0.07)$, IOS is $0.03(-0.22)$, and Industry Homogeneity is $0.15(0.11)$. We next focus on other hiring firm characteristics. The mean (median) firm size is \$1,496 (\$294) million dollars, while the mean (median) Leverage is $0.74(0.11)$. Consistent with findings from prior research on CEO turnover (e.g., Coughlan and Schmidt 1985; Warner et al. 1988; Weisbach 1988), hiring firms have generally performed poorly prior to the CEO transition, with a mean ROA of -0.07 and Return of -0.09 . Also, consistent with the market uncertainty about firm performance preceding the new CEO appointment,

\footnotetext{
${ }^{8}$ For stock awards of a fixed number of securities, we estimate the dollar value of the grant by multiplying the grant date stock price by the number of securities. For stock option awards of a fixed number of underlying securities, we estimate the option grant values using the same parameter assumptions used to estimate \$Sensitivity.
} 


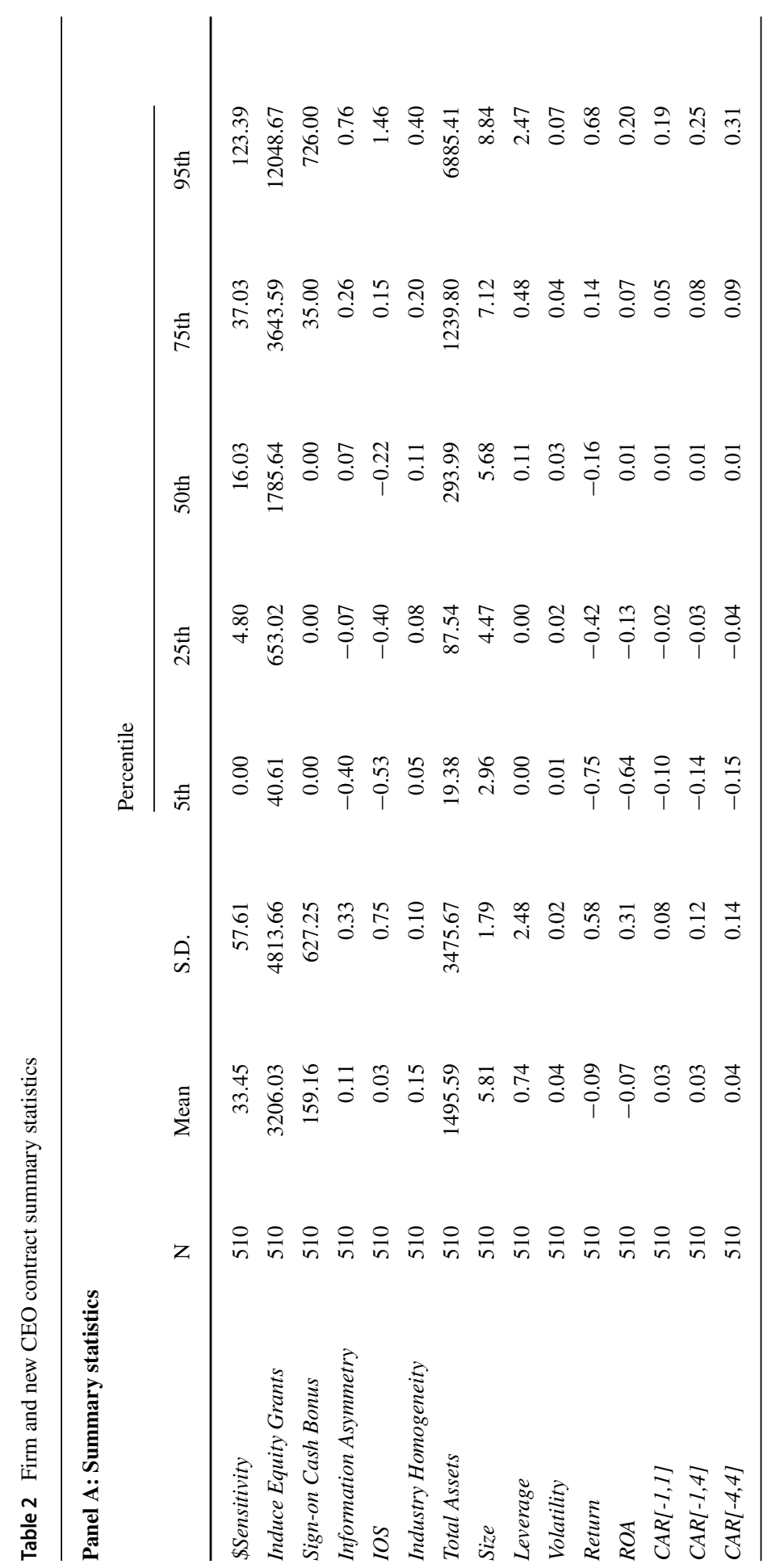




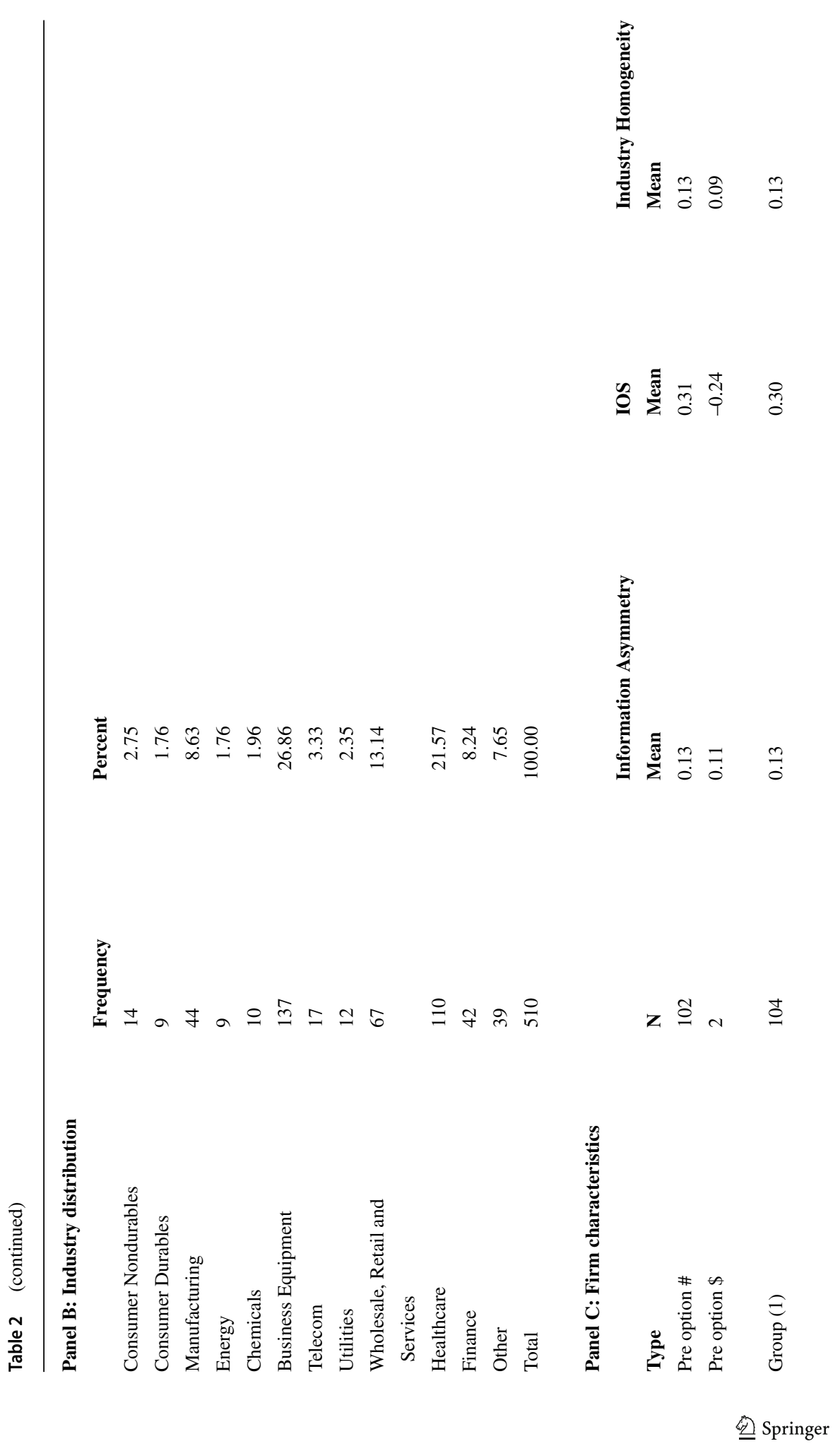




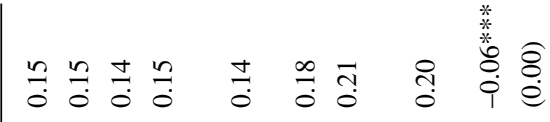

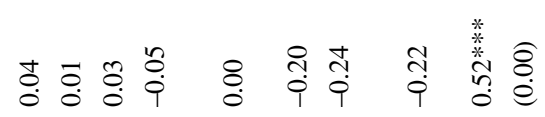

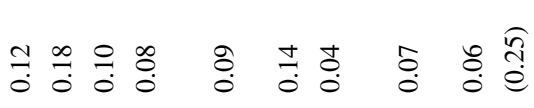

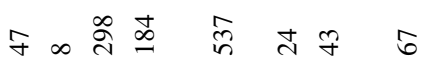

过

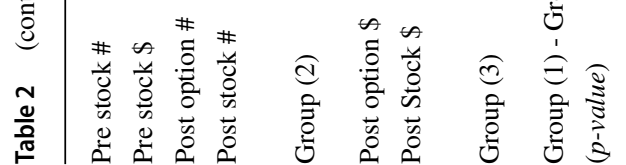

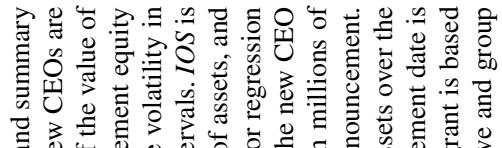

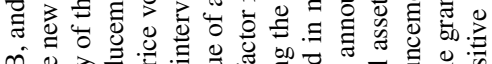

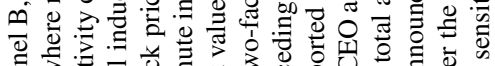

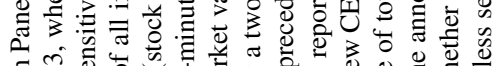

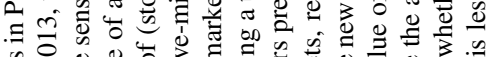

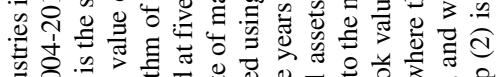

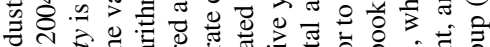

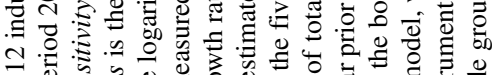

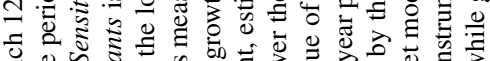

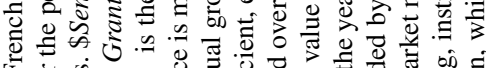

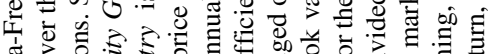

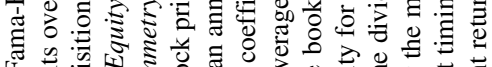

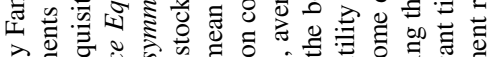

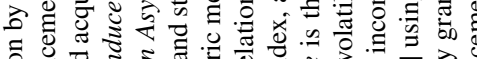

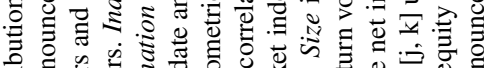

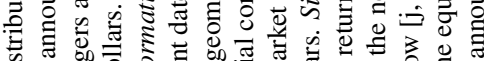

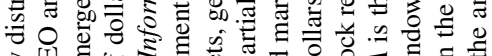

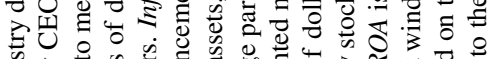

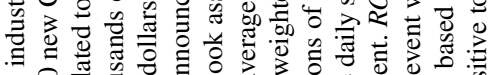

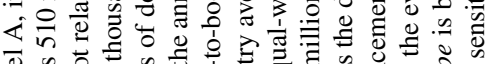
d

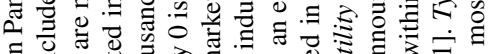
至.

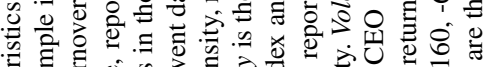

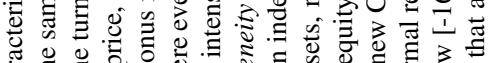

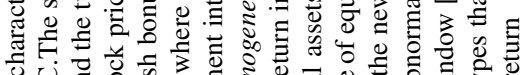

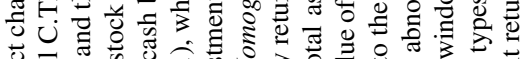

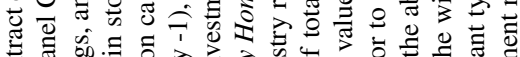

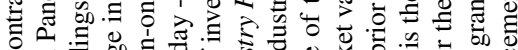

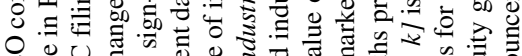

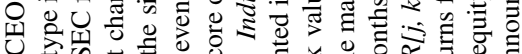

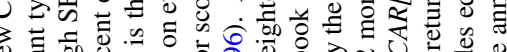

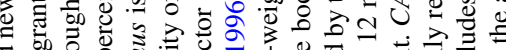

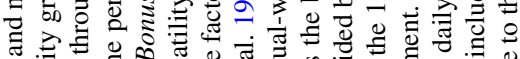

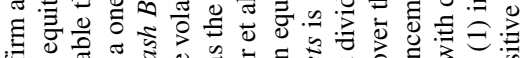

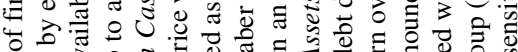

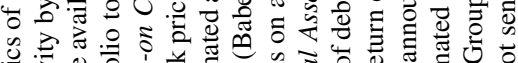
此

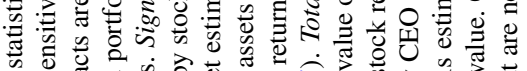

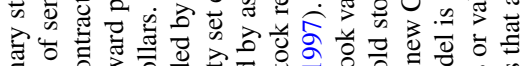

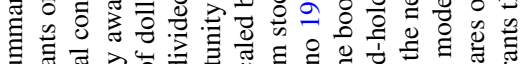

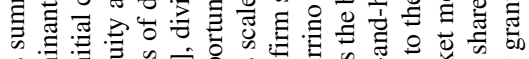

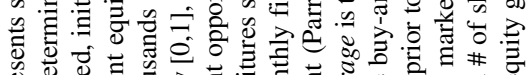

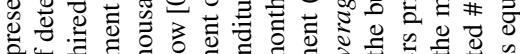
运栲 要. .

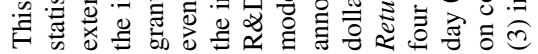


the return volatility over the 12 months prior to the new CEO announcement return is $0.04(0.03) .{ }^{9}$ These summary statistics are consistent with the broad variation in firms represented in our sample.

The mean (median) three-day abnormal new CEO announcement return is three percent (one percent). ${ }^{10}$ The positive average new CEO announcement return is consistent with prior studies that find the stock market usually reacts positively to external CEO replacements following CEO turnovers (e.g., Huson et al. 2004). The standard deviation of the new CEO announcement return is 0.08 , which suggests that new CEOs with equity grants that are sensitive to the new CEO announcement return bear substantial risk around the announcement of their hiring. The average announcement return of $3 \%$ yields a change in wealth of $\$ 100,350$ for the average contract sensitivity over the three-day window of the new CEO announcement return. ${ }^{11}$

Panel B reports the industry distribution of the hiring firms for Fama-French 12 industries. Although all 12 industries are represented in the sample, business equipment and healthcare constitute the greatest proportion of the sample. ${ }^{12}$

Table 2 Panel $\mathrm{C}$ presents the mean of the economic determinants by grant type. We group the grants based on the sensitivity of the grant type. Group (1) includes the equity grant types that are the most sensitive to the announcement return, while group (2) is less sensitive and group (3) includes equity grants that are not sensitive to the announcement return. We find that Information Asymmetry is greater, but not significantly so, in group (1). We find that IOS (Industry Homogeneity) is significantly greater (lower) in group (1) than in group (3) ( $p$-value $<0.01)$. These trends are generally consistent with our hypotheses.

\subsection{Information asymmetry and inducement grant sensitivity}

Table 3 presents test results of the hypotheses as described in Equation (1). The results reported in Column (1) focus on information asymmetry. We find a positive

\footnotetext{
${ }^{9}$ We compare our sample to firms in ExecuComp over our sample period in untabulated results. We find that our sample firms operate in less homogeneous industries with greater investment opportunity sets than ExecuComp firms. Also, as expected, our sample firms are significantly smaller with greater leverage than ExecuComp firms. Focusing on performance, as expected, our sample firms perform significantly worse than firms in the ExecuComp sample on both ROA and Return. At the same time, the return volatility is higher for our sample firms. Finally, the grant date fair value of annual equity grants and the delta of the annual equity grants are significantly smaller in our sample than firms in ExecuComp, where annual equity grants include those granted after the inducement grants but before the end of the first year of employment. t-tests of the differences are all significant at $p$-value $<0.01$. We also find that our sample spans a broader set of smaller firms than that of Fee and Hadlock (2003), who focus on the largest 1,000 firms in their sample period.

${ }^{10}$ Fifty-nine percent of the sample report a positive three-day abnormal announcement return.

${ }^{11}$ This three-day return is greater than the average 2\% 30-day return and \$30,000 increase in wealth following stock options granted in advance of "good news" documented by Yermack (1997). It is also greater than the 3\% 30-day abnormal return and \$92,500 change in wealth following unscheduled equity grants in advance of voluntary disclosure documented by Aboody and Kasznik (2000). Heron and Lie (2007) find a similar 30-day abnormal return for suspected back-dated option grants.

${ }^{12}$ In untabulated results, we find that each year in the sample period is well represented, with a slightly larger number of observations occurring during the years 2005-2008.
} 
Table 3 Inducement grant sensitivity and adverse selection problems

$$
\begin{aligned}
\text { \$Sensitivity }= & \beta_{0}+\beta_{1} \text { Information Asymmetry }+\beta_{2} I O S+\beta_{3} \text { Industry Homogeneity } \\
& +\beta_{4} \text { Size }+\beta_{5} \text { Leverage }+\beta_{6} \text { Volatility }+\beta_{7} \text { Return } \\
& +\beta_{8} \text { ROA }+\Sigma_{i} \beta_{i} \text { Year }_{i}+\varepsilon
\end{aligned}
$$

(1)

13.752 ***

(2.437)

IOS

Information Asymmetry

(2)

(3)

(4)

Industry Homogeneity

$$
\text { Size }
$$

(3.950)

Leverage

Volatility

Return

$R O A$

Constant

Observations

Pseudo $R^{2}$

$$
16.703 * * *
$$

$-119.369 * * *$
$(-3.370)$

$12.516^{* * * *}$
$(6.079)$

$$
\text { (-1.075) }
$$$$
-49.170 * *
$$$$
(-2.386)
$$$$
-58.248 * * *
$$

510

0.013

$$
510
$$

0.015
(6.079)

$-2.782 *$

$(-1.685)$

338.066*

6.689

$-41.687 * *$

$(-2.273)$

510

0.016
$15.250 * * *$

$14.486^{* * * *}$

$-106.976^{* * *}$

0.019

This table reports results from estimating Tobit regressions of \$Sensitivity on proxies for adverse selection problems and control variables. The model includes unreported year fixed effects. The full sample includes 510 new CEO announcements over the period 2004-2013, where new CEOs are externally hired, initial contracts are available through SEC filings, and the turnovers are not related to mergers and acquisitions. \$Sensitivity is the sensitivity of the value of the inducement equity-award portfolio to a one percent change in stock price, in thousands of dollars. Information Asymmetry is measured as the logarithm of (stock price volatility in event window [0,1], divided by stock price volatility on event day -1 ), where event day 0 is the announcement date and stock price is measured at five-minute intervals. Industry Homogeneity is the industry average partial correlation coefficient, estimated using a two-factor regression model of monthly firm stock returns on an equal-weighted industry return index and an equal-weighted market index, averaged over the five years preceding the new CEO announcement (Parrino 1997). IOS is the investment opportunity set estimated as the factor score of investment intensity, market-to-book assets, geometric mean annual growth rate of market value of assets, and R\&D expenditures scaled by assets (Baber et al. 1996). Size is the logarithm of book value of total assets, reported in millions of dollars. Leverage is the book value of debt divided by the market value of equity. Volatility is the daily stock return volatility for the year prior to the new CEO announcement. Return is the buy-and-hold stock return over the 12 months prior to the new CEO announcement. ROA is the net income divided by the book value of total assets over the four quarters prior to the new CEO announcement. *, **, and *** indicate $p<0.10$, $p<0.05$, and $p<0.01$, based on one-tailed tests when there is a predicted sign, two-tailed otherwise. $t$-statistics are in parentheses 
and significant coefficient on Information Asymmetry, $\beta_{1}>0$ ( $p$-value $\left.<0.01\right)$, which supports the prediction in $\mathrm{H} 1$ that the sensitivity of inducement grants to the announcement return increases in information asymmetry.

The results reported in Column (2) focus on the relation between inducement grant sensitivity and the importance of resolving adverse selection related to the CEO's appetite for risk. In support of $\mathrm{H} 2$, we find that firms facing greater potential loss from underinvestment in valuable risky projects grant inducement equity awards that are more sensitive to the new CEO announcement return, as evidenced by a positive and significant coefficient on IOS, $\beta_{2}>0$ ( $p$-value $\left.<0.01\right)$.

The results reported in Column (3) focus on our third hypothesis-that inducement grant sensitivity to the new CEO announcement return increases in the cost of identifying and replacing a less productive CEO. Consistent with $\mathrm{H} 3$, we find that firms operating in more homogeneous industries grant inducement equity awards that are less sensitive to the new CEO announcement return, as evidenced by $\beta_{3}<0$ ( $p$-value $<0.01)$.

Table 3 Column (4) reports the results of the complete model, where we continue to find support for our hypotheses. Finally, the coefficients on Size (Leverage) are positive (negative) and significant in all models, while the coefficients on Volatility are positive and significant in Column (3) and Column (4) and the coefficient on ROA is positive and significant in Column (4). ${ }^{13}$

We test the robustness of our results to an alternative measure of information asymmetry. Following Ang et al. (2006), we measure the logarithm of the ratio of idiosyncratic volatility in the event window $[0,20]$ to daily idiosyncratic volatility in the pre-event window $[-21,-1] .{ }^{14}$ This alternative proxy is measured over a longer horizon than Information Asymmetry. Pan et al. (2015) find evidence that this measure of stock return volatility around CEO turnovers is a proxy for the market's uncertainty about the CEO's skill. When we consider this alternative measure of information asymmetry, we continue to find, in untabulated results, evidence in support of our hypotheses. We also consider market-to-book and research and development expense individually as measures of the potential loss from underinvestment in valuable risky projects. We find, in untabulated results, positive and significant coefficients on these measures, and we continue to find support for our other hypotheses.

In untabluated results, we estimate Equation (1) using the natural log transformation of \$Sensitivity and the independent variables with skewness greater than two; $I O S$, Leverage, and Return. We find qualitatively similar results in this specification to those reported in Table 3. Chang et al. (2015) suggest that firms compensate newly hired CEOs for the the risk of default. Although we do not predict a relation between default risk and \$Sensitivity, we test the robustness of our results to measures of default risk including the probability of default and Altman Z-score (Altman 1968;

\footnotetext{
${ }^{13}$ When we measure \$Sensitivity with the time-to-expiration of 5 years or 10 years, and dividend yield of 0 we find qualitatively similar results.

${ }^{14}$ Daily idiosyncratic return is the residual return from the Fama-French three-factor model. We also use market adjusted return and total raw return in untabulated results to measure daily return, and the results are similar.
} 
Bharath and Shumway 2008). Our primary inferences are robust to the inclusion of these measures.

\subsection{Market reaction and performance}

The hypotheses assume that CEOs expect the market to react to the announcement in a way that is consistent with the private information some investors have about the CEO. It follows that CEOs who expect the market to react favorably to the announcement of their appointment are willing to accept inducement grants that are more sensitive to the new CEO announcement return, and that the market reaction is consistent with the CEO's expectation. To test this assumption, we examine the relation between the sensitivity of the inducement grant to the announcement return and the market reaction to the announcement in the following empirical model:

$$
\begin{aligned}
C A R= & \gamma_{0}+\gamma_{1} \text { \$Sensitivity }+\gamma_{2} \text { Size }+\gamma_{3} \text { Volatility }+\gamma_{4} \text { Return } \\
& +\gamma_{5} \text { ROA }+\Sigma_{i} \gamma_{i} \text { Year }_{i}+\varepsilon
\end{aligned}
$$

We measure the cumulative abnormal announcement return, $C A R$, for the threeday window $[-1,1]$ surrounding the announcement date. We also consider longer announcement return windows - $[-1,4]$ and $[-4,4]$ - that allow for the possibility that information about the new CEO announcement is revealed before the press release and allow for a delayed reaction to the new CEO announcement. ${ }^{15}$ To calculate expected returns, we estimate the market model using daily stock returns from the [-160, -61] trading-day window. We include the following control variables: Size, Return, ROA, and Volatility. ${ }^{16}$

We find, in Table 4, that the abnormal return around the new CEO announcement is positively and significantly related to \$Sensitivity. This relation, which is robust to all three return windows, supports the assumption that incoming CEOs accept contractual features that are sensitive to the announcement return when they expect the market to react positively to the new CEO appointment and the market reaction is consistent with the CEO's expectation.

We consider the possibility that CEOs misrepresent their type by accepting inducement grants that are more sensitive to the announcement return. However, we expect the positive reaction to the announcement to reverse as the truth about the CEO is revealed (Pan et al. 2015). Therefore, a misrepresenting CEO that accepts inducement grants that are more sensitive to the announcement must take advantage of the inflated price and sell the securities before their true type is revealed. To test this conjecture, we collect SEC Form 4 insider-trading filings for the newly appointed CEOs

\footnotetext{
${ }^{15}$ In untabulated results, we find consistent results using the market adjusted return and the cumulative raw return.

${ }^{16}$ Bonnier and Bruner (1989) show that stock returns to the announcement of new external CEOs are negatively associated with size and performance prior to the CEO turnover.
} 
Table 4 CEO announcement market reaction and inducement grant sensitivity

$$
\begin{aligned}
C A R= & \gamma_{0}+\gamma_{1} \$ \text { Sensitivity }+\gamma_{2} \text { Size }+\gamma_{3} \text { Volatility }+\gamma_{4} \text { Return }+\gamma_{5} \text { ROA } \\
& +\Sigma_{i} \gamma_{i} \text { Year }_{i}+\varepsilon
\end{aligned}
$$

\begin{tabular}{llll} 
& $C A R[-1,1]$ & $C A R[-1,4]$ & $C A R[-4,4]$ \\
\hline SSensitivity & $0.112^{* *}$ & $0.195^{* *}$ & $0.305^{* * *}$ \\
& $(2.115)$ & $(2.008)$ & $(2.967)$ \\
Size & -0.001 & -0.002 & -0.001 \\
& $(-0.852)$ & $(-0.612)$ & $(-0.195)$ \\
Volatility & $1.105^{* * *}$ & $1.382^{*}$ & $1.507^{* *}$ \\
& $(3.454)$ & $(2.172)$ & $(2.392)$ \\
Return & $-0.025^{* * *}$ & $-0.043^{* * *}$ & $-0.053^{* * *}$ \\
& $(-4.006)$ & $(-6.061)$ & $(-4.578)$ \\
ROA & -0.008 & -0.001 & -0.004 \\
& $(-0.482)$ & $(-0.021)$ & $(-0.150)$ \\
Constant & -0.014 & -0.017 & -0.029 \\
& $(-0.705)$ & $(-0.429)$ & $(-0.765)$ \\
Observations & 510 & 510 & 510 \\
Adjusted $R^{2}$ & 0.091 & 0.091 & 0.086 \\
\hline
\end{tabular}

This table reports results from estimating OLS regressions of CAR on \$Sensitivity and control variables. The model includes unreported year fixed effects. The full sample includes 510 new CEO announcements over the period 2004-2013, where new CEOs are externally hired, initial contracts are available through SEC filings, and the turnovers are not related to mergers and acquisitions. $C A R[j, k]$ is the abnormal return within the event window $[\mathrm{j}, \mathrm{k}]$ using the market model, where the announcement date is day 0 and the market model is estimated with daily returns for the window [-160, -61]. \$Sensitivity is the sensitivity of the value of the inducement equity award portfolio to a one percent change in stock price, in thousands of dollars. Size is the logarithm of the book value of total assets. Volatility is the daily return volatility for the year prior to the new CEO announcement. Return is the buy-and-hold stock return over the 12 months prior to the new CEO announcement. $R O A$ is the net income divided by the book value of total assets over the four quarters prior to the new CEO announcement. *,**, and *** indicate $p<0.10, p<0.05$, and $p<0.01$, based on one-tailed tests when there is a predicted sign, two-tailed otherwise. $t$-statistics are in parentheses

in the six months following the appointment. We find no evidence from these filings that CEOs liquidate shares during this period, which suggests that CEOs do not misrepresent their type to benefit from a short-run stock price increase by selling their equity holdings in the firm.

We also consider whether the sensitivity of the inducement grant to the new CEO announcement return is related to the accounting and market performance of the firm over the year following the new CEO appointment. We estimate industry adjusted ROA and market performance over the year following the new CEO appointment as a function of \$Sensitivity, and the other economic determinants included in Equation 2. In Table 5, we find a positive relation between industry adjusted ROA 
Table 5 Ex post performance and inducement grant sensitivity

$$
\begin{aligned}
\text { Ex Post Performance }= & \beta_{0}+\beta_{1} \$ \text { Sensitivity }+\beta_{2} \text { Size }+\beta_{3} \text { Volatility }+\beta_{4} \text { Return } \\
& +\beta_{5} \text { ROA }+\Sigma_{i} \beta_{i} \text { Year }{ }_{i}+\varepsilon
\end{aligned}
$$

Ind. Adj. ROA

Ind. Adj. Return

\begin{tabular}{lll}
\hline Sensitivity & $3.180^{*}$ & -0.014 \\
& $(1.646)$ & $(-0.046)$ \\
Size & $-0.210^{* *}$ & 0.012 \\
\multirow{3}{*}{ Volatility } & $(-2.834)$ & $(0.743)$ \\
& -6.617 & $6.296^{* *}$ \\
Return & $(-1.164)$ & $(2.962)$ \\
& 0.022 & -0.004 \\
ROA & $(0.107)$ & $(-0.105)$ \\
& -0.978 & $0.243 *$ \\
Constant & $(-0.857)$ & $(2.029)$ \\
& $6.072^{* * *}$ & -0.258 \\
Observations & $(11.833)$ & $(-1.711)$ \\
Adjusted $R^{2}$ & 485 & 485 \\
\hline
\end{tabular}

This table reports results from estimating OLS regressions of Ex Post Performance on \$Sensitivity and control variables. The model includes unreported year fixed effects. The sample includes 485 new CEO announcements over the period 2004-2013, where new CEOs are externally hired, initial contracts are available through SEC filings, and the turnovers are not related to mergers and acquisitions. \$Sensitivity is the sensitivity of the value of the inducement equity-award portfolio to a one percent change in stock price, in thousands of dollars. Ind. Adj. ROA is the net income divided by the book value of total assets over the four quarters after the announcement date minus the industry average $R O A$ over the same period. Ind. Adj. Return is the buy-and-hold stock return over the 12 months after the new CEO announcement minus the industry average Return over the same period. Size is the logarithm of book value of total assets, reported in millions of dollars. Volatility is the daily stock return volatility for the year prior to the new CEO announcement. Return is the buy-and-hold stock return over the 12 months prior to the new CEO announcement. ROA is the net income divided by the book value of total assets over the four quarters prior to the new CEO announcement. *,**, and *** indicate $p<0.10, p<0.05$, and $p<0.01$, based on one-tailed tests when there is a predicted sign, two-tailed otherwise. $t$-statistics are in parentheses

and inducement grant sensitivity $(p$-value $<0.10) .{ }^{17}$ This result supports our conjecture that inducement grant sensitivity separates more productive CEOs when it benefits the firm. However, we find no evidence of a significant relation between \$Sensitivity and industry adjusted market performance over the year following the new CEO appointment. This lack of a significant relation suggests that the market

\footnotetext{
${ }^{17}$ We are able to measure industry adjusted $R O A$ and Return over the year following the new CEO appointment for 485 firms.
} 
impounds the expected effect of the new CEO appointment at the time of the new CEO announcement. ${ }^{18}$

We also consider whether firms bundle additional information around the new CEO announcement in a way that systematically influences the new CEO announcement return. To identify additional information bundled with the new $\mathrm{CEO}$ announcement, we first examine 8-K filings over the window one trading day before through four trading days after the new CEO announcement. We then examine 8-K Items included in the those filings. The 8-K filing of the new CEO announcement includes Item 5.02, the new CEO announcement; Item 9.01, the exhibit of the employment agreement with the new CEO; and often Item 1.01, material contracts. In our sample, 274 file 8-Ks that only include these items in the 6-day window we examine. The remaining 236 file $8-\mathrm{Ks}$ that include additional items.

We then examine whether the new CEO announcement return in the $[-1,4]$ window differs for firms that file 8-Ks that include additional 8-K Items. Specifically, we test whether firms that file 8-Ks that only include Items 1.01, 5.02, and 9.01 have returns that are significantly different than firms that file 8 -Ks that include additional items. In untabulated results, we do not find a significant difference in the average returns between the two groups. These results suggest that firms do not disclose additional information that significantly and systematically influences the stock price around the new CEO announcement.

Together, the results support our assumption that CEOs who expect the market to react favorably to the announcement of their appointment accept inducement grants that are more sensitive to the new CEO announcement return. We also provide evidence that accounting performance is positively related to the sensitivity of the inducement grant to the announcement return, which supports our conjecture that contractual features help firms resolve information asymmetry about the CEO. The lack of a significant relation between inducement grant sensitivity and long-term stock performance suggests that the market impounds expected performance at the new CEO announcement, on average. Finally, we find no evidence that firms disclose additional information to increase the stock price around the new CEO announcement.

\subsection{Factors that reduce information asymmetry}

\subsubsection{Executive search firm}

In some instances, the board of directors will retain an executive search firm to aid in the selection of a new CEO. Executive search firms find suitable CEO candidates and provide additional information, which reduces information asymmetry.

Firms choose whether to retain an executive search firm, and are more likely to do so when information asymmetry about the CEO and the importance of addressing the adverse selection problem are higher. However, the firm chooses whether to

\footnotetext{
${ }^{18}$ We find no evidence of significant relation when we estimate the change in the industry adjusted ROA and market return over the year prior to and the year following the new CEO appointment.
} 
retain the executive search firm before contracting with the new CEO. Therefore, boards of directors design the new CEO's contract after receiving information from the executive search firm. To the extent that executive search firms reduce information asymmetry about the incoming CEO, we predict a negative relation between the sensitivity of the inducement grant to the announcement return and the use of an executive search firm.

To construct Search Firm, we first collect hiring firm proxy statements for the year prior to and the year of, the new CEO start. We then search the proxy statements for language indicating that the firm retained a search firm to identify key executives in the year. ${ }^{19}$ If one of the proxy statements indicated the use of a search firm, we set Search Firm to one, and zero otherwise. We find that $24 \%$ of our sample firms retained an executive search firm. To test the effect of the executive search firm on the sensitivity of the inducement grant, we estimate the following empirical model:

$$
\begin{aligned}
\text { \$Sensitivity }= & \beta_{0}+\beta_{1} \text { Information Asymmetry }+\beta_{2} I O S \\
& +\beta_{3} \text { Industry Homogeneity } \\
& +\beta_{4} \text { Search Firm }+\beta_{5} \text { Size }+\beta_{6} \text { Leverage }+\beta_{7} \text { Volatility } \\
& +\beta_{8} \text { Return }+\beta_{9} R O A+\Sigma_{i} \beta_{i} \text { Year }_{i}+\varepsilon
\end{aligned}
$$

Table 6 Column (1) reports the results from estimating Equation (3). Consistent with our conjecture, we find a negative and significant coefficient on Search Firm ( $p$-value $<0.01$ ). We also continue to find evidence in support of our primary hypotheses after including Search Firm.

\subsubsection{CEO experience}

We first consider internal CEO appointments, where information asymmetry is likely to be less severe because of the candidate's history with the firm. To identify internal CEO appointments, we identified all non-interim CEOs appointed during our sample period using director and officer change data from Audit Analytics. We excluded any appointments associated with M\&A, bankruptcy, and change in control, or that indicate the CEO was previously a CEO of the same company. Of the remaining observations, any that indicate the CEO is assuming an additional position or changing positions within the company are designated as inside CEO appointments. For those that do not directly indicate that the new CEO is a current employee of the company, we use the CEO name and firm CIK to identify all insider filings (SEC Forms 3, 4 , and 5) prior to the new CEO announcement date. If any insider filings for the new CEO are found before 90 days prior to the new CEO announcement, then we also

\footnotetext{
${ }^{19}$ We searched for the terms "search" and "firm" within 50 characters of one another, which nearly always matched "search firm." For each resulting match, we then searched the surrounding 200 characters for verbs in the past tense that were commonly used to describe either the retention of a search firm or the hiring recommendations of a search firm (e.g., engaged, retained, utilized, hired, recommended, proposed, identified). Occasionally, the resulting matches identified the use of a search firm to identify directors. We assume that, if a search firm is used to identify a director, then it is also used to identify a new CEO, and we therefore do not distinguish director from CEO matches.
} 
Table 6 Inducement grant sensitivity, adverse selection problems, and other ways to reduce information asymmetry

$$
\begin{aligned}
\text { SSensitivity }= & \beta_{0}+\beta_{1} \text { Information Asymmetry }+\beta_{2} \text { IOS }+\beta_{3} \text { Industry Homogeneity } \\
& +\beta_{4} \text { Information Asymmetry Reduction }+\beta_{5} \text { Size }+\beta_{6} \text { Leverage } \\
& +\beta_{7} \text { Volatility }+\beta_{8} \text { Return }+\beta_{9} R O A+\Sigma_{i} \beta_{i} \text { Year } r_{i}+\epsilon
\end{aligned}
$$

\begin{tabular}{|c|c|c|c|c|}
\hline & (1) & (2) & (3) & (4) \\
\hline Information Asymmetry & $\begin{array}{l}15.402^{* * * *} \\
(3.034)\end{array}$ & $\begin{array}{l}9.298 * * \\
(2.270)\end{array}$ & $\begin{array}{l}14.549 \text { *** } \\
(3.512)\end{array}$ & $\begin{array}{l}15.634 * * * \\
(2.811)\end{array}$ \\
\hline IOS & $\begin{array}{l}13.580^{* * * *} \\
(3.699)\end{array}$ & $\begin{array}{l}14.385^{* * * *} \\
(4.501)\end{array}$ & $\begin{array}{l}14.968^{* * * *} \\
(3.768)\end{array}$ & $\begin{array}{l}15.352^{* * *} \\
(3.740)\end{array}$ \\
\hline Industry Homogeneity & $\begin{array}{l}-108.521 * * * \\
(-2.895)\end{array}$ & $\begin{array}{l}-104.946^{* * * *} \\
(-4.438)\end{array}$ & $\begin{array}{l}-100.228^{* * * *} \\
(-2.716)\end{array}$ & $\begin{array}{l}-115.661 \text { *** } \\
(-2.844)\end{array}$ \\
\hline Search Firm & $\begin{array}{l}-12.851 * * * \\
(-2.834)\end{array}$ & & & \\
\hline Outside CEO & & $\begin{array}{l}35.778^{* * *} \\
(7.573)\end{array}$ & & \\
\hline CEO Experience & & & $\begin{array}{l}7.357 * * \\
(2.585)\end{array}$ & \\
\hline Board Overlap & & & & $\begin{array}{l}5.670 \\
(0.425)\end{array}$ \\
\hline Size & $\begin{array}{l}14.260 \text { *** } \\
(6.670)\end{array}$ & $\begin{array}{l}10.630 * * * \\
(13.086)\end{array}$ & $\begin{array}{l}13.872^{* * *} \\
(6.565)\end{array}$ & $\begin{array}{l}14.482^{* * * *} \\
(6.267)\end{array}$ \\
\hline Leverage & $\begin{array}{l}-2.845^{*} \\
(-1.850)\end{array}$ & $\begin{array}{l}-5.422 * * \\
(-2.420)\end{array}$ & $\begin{array}{l}-2.854^{*} \\
(-1.922)\end{array}$ & $\begin{array}{l}-2.633 \\
(-1.533)\end{array}$ \\
\hline Volatility & $\begin{array}{l}360.175^{*} \\
(1.946)\end{array}$ & $\begin{array}{l}449.254^{* * * *} \\
(3.545)\end{array}$ & $\begin{array}{l}397.791 * * \\
(2.130)\end{array}$ & $\begin{array}{l}423.948^{*} \\
(1.750)\end{array}$ \\
\hline Return & $\begin{array}{l}6.937 * \\
(1.860)\end{array}$ & $\begin{array}{l}-1.003 \\
(-0.175)\end{array}$ & $\begin{array}{l}6.879 * \\
(1.806)\end{array}$ & $\begin{array}{l}8.428 * \\
(1.797)\end{array}$ \\
\hline$R O A$ & $\begin{array}{l}10.277 \\
(1.547)\end{array}$ & $\begin{array}{l}12.563^{* * * *} \\
(3.062)\end{array}$ & $\begin{array}{l}12.762 * \\
(1.867)\end{array}$ & $\begin{array}{l}15.162 * \\
(1.881)\end{array}$ \\
\hline Constant & $\begin{array}{l}-54.287 * * * \\
(-2.770)\end{array}$ & $\begin{array}{l}-87.275^{* * *} \\
(-13.107)\end{array}$ & $\begin{array}{l}-57.534 * * * \\
(-2.913)\end{array}$ & $\begin{array}{l}-56.676^{* * *} \\
(-2.623)\end{array}$ \\
\hline Observations & 510 & 668 & 510 & 471 \\
\hline Pseudo $R^{2}$ & 0.020 & 0.031 & 0.020 & 0.020 \\
\hline
\end{tabular}


Table 6 (continued)

This table reports results from estimating Tobit regressions of \$Sensitivity on proxies for adverse selection problems and control variables. The model includes unreported year fixed effects. The full sample includes 510 new CEO announcements over the period 2004-2013, where new CEOs are externally hired, initial contracts are available through SEC filings, and the turnovers are not related to mergers and acquisitions. The sample for column (2) include 334 outside CEOs and the matched inside CEOs that are hired by a firm in the same industry and year, and with Size and Return closest to the sample firm. \$Sensitivity is the sensitivity of the value of the inducement equity award portfolio to a one percent change in stock price, in thousands of dollars. Information Asymmetry is measured as the logarithm of (stock price volatility in event window [0,1], divided by stock price volatility on event day -1 ), where event day 0 is the announcement date and stock price is measured at five-minute intervals. IOS is the investment opportunity set estimated as the factor score of investment intensity, market-to-book assets, geometric mean annual growth rate of market value of assets, and R\&D expenditures scaled by assets (Baber et al. 1996). Industry Homogeneity is the industry average partial correlation coefficient, estimated using a two-factor regression model of monthly firm stock returns on an equal-weighted industry return index and an equal-weighted market index, averaged over the five years preceding the new CEO announcement (Parrino 1997). Search Firm is an indicator of using an executive search firm. Outside CEO is an indicator that equals 1 for outside CEO hires, and 0 otherwise. CEO Experience is measured as the principal component of prior CEO experience, which include $\mathrm{CEO}$ age, being a $\mathrm{CEO}$ before, number of prior $\mathrm{CEO}$ positions, prior CEO tenure, number of industries with prior CEO experience, and prior CEO experience in the same industry as the hiring firm. Board Overlap is an indicator for whether the incoming CEO and any board member previously served on the same board prior to the new CEO appointment or whether the incoming CEO worked at a firm where any board member of the hiring firm was employed or served as a board member. Size is the logarithm of book value of total assets, reported in millions of dollars. Leverage is the book value of debt divided by the market value of equity. Volatility is the daily stock return volatility for the year prior to the new CEO announcement. Return is the buy-and-hold stock return over the 12 months prior to the new CEO announcement. ROA is the net income divided by the book value of total assets over the four quarters prior to the new CEO announcement. *, **, and *** indicate $p<0.10, p<0.05$, and $p<0.01$, based on one-tailed tests when there is a predicted sign, two-tailed otherwise. $t$-statistics are in parentheses

identify these as inside CEO appointments. For each external CEO appointment in our main sample, we match an inside CEO appointment by a firm in the same industry and year, where Size and Return are closest to the sample CEO's firm. We were able to identify matched inside CEO appointments for 334 outside CEO appointments in our main sample. In Table 6 Column (2), we estimate Equation (3) using Outside CEO in lieu of Search Firm. We find a positive and significant coefficient on the indicator for CEOs from outside the firm.

In addition, there is less information asymmetry about CEOs with more experience. At the same time, CEOs with more experience may accept inducement grants that are more sensitive to the announcement return because they expect the market to respond favorably to their appointment. To the extent that the reduction in information asymmetry from CEO experience is the dominating effect, we predict a negative relation between CEO experience and \$Sensitivity.

We measure CEO experience with the age of the new CEO at the time of the appointment, whether the incoming CEO work ed as a CEO prior to the new CEO appointment, the number of prior CEO positions, the number of years spent as a CEO in the past, the number of unique industries worked as a CEO in the past, and whether a prior CEO position was with a firm in the same industry as the hiring firm. The 
average CEO age is 51.22, and $295(58 \%)$ have worked as a CEO prior to the new appointment. Among the CEOs with prior CEO experience, more than half have held just one prior CEO position, and the average tenure for prior CEO appointments is 3.32 years. In addition, most new CEOs with prior CEO experience worked as CEO in only one industry prior to the new appointment, and $45 \%$ of them worked in the same industry as their new employer.

We conduct a factor analysis of the CEO experience to identify those characteristics that are correlated along the same dimension. The factor analysis produces one factor with an eigenvalue greater than 1, CEO Experience, which captures the common variation in the CEO experience measures. In Table 6 Column (3), we estimate Equation (3) using CEO Experience in lieu of Search Firm. We find a positive relation between $\$$ Sensitivity and CEO Experience. We infer from this result that the reduction in information asymmetry from CEO experience is not the dominating effect.

\subsubsection{Board-CEO employment overlap}

Boards of directors with additional experience with the $\mathrm{CEO}$ are more informed about the newly appointed CEO. If CEO-board connectedness substantially reduces information asymmetry, we predict a negative relation between CEO-board connectedness and \$Sensitivity.

We measure CEO-board connectedness with Board Overlap, an indicator for whether the incoming CEO and any board member previously served on the same board prior to the new CEO appointment or whether the incoming CEO worked at a firm where any board member of the hiring firm was employed or served as a board member. We obtain employment history for the CEO and directors from Boardex. The subsample with non-missing Board Overlap contains 471 outside CEOs.

In Table 6 Column (4), we estimate Equation (3) using Board Overlap in lieu of Search Firm. We find no relation between the sensitivity of the inducement grant and these measures of board experience with the CEO. One explanation for the lack of a result is that information from prior experience is not equivalent to that obtained specifically to evaluate the candidate for the new CEO appointment.

\subsection{Risk, other compensation, and governance}

Hiring firms may mitigate the risk of inducement grants that are sensitive to the announcement return by entering into an implicit contract where the firm compensates the incoming CEO for a negative CEO announcement reaction. To this end, we investigate whether firms grant additional equity or reprice stock options within one month of the new CEO announcement return. To test this, we collect Form 4 filings for the CEOs and find no unscheduled grants or repricing during that period. The lack of additional grants or repricing of stock options suggests that the firm does not reduce the risk associated with the announcement return by compensating the CEO for any loss of value that results from a negative new CEO announcement return. We also consider that cash sign-on bonuses may compensate the CEO for bearing the risk of inducement grants that are sensitive to the announcement return. We include 
Table 7 Inducement grant sensitivity, adverse selection problems and other equity compensation

$$
\begin{aligned}
\text { \$Sensitivity }= & \beta_{0}+\beta_{1} \text { Information Asymmetry }+\beta_{2} \text { IOS }+\beta_{\mathbf{3}} \text { Industry Homogeneity } \\
& +\beta_{4} \text { Size }+\beta_{5} \text { Leverage }+\beta_{6} \text { Volatility }+\beta_{7} \text { Return }+\beta_{8} \text { ROA } \\
& +\beta_{9} \text { Annual Grants }(\text { Delta })+\Sigma_{i} \beta_{i} \text { Year }_{i}+\varepsilon
\end{aligned}
$$

\begin{tabular}{lll}
\hline Information Asymmetry & $11.811^{* *}$ & $11.765^{* *}$ \\
IOS & $(1.861)$ & $(1.875)$ \\
& $11.439^{* * *}$ & $11.321^{* * *}$ \\
Industry Homogeneity & $(2.644)$ & $(2.671)$ \\
& $-81.972^{* *}$ & $-80.225^{* *}$ \\
Size & $(-2.224)$ & $(-2.155)$ \\
& $9.001^{* * *}$ & $8.647 * * *$ \\
Leverage & $(3.737)$ & $(3.563)$ \\
& -2.203 & -2.142 \\
Volatility & $(-1.538)$ & $(-1.477)$ \\
& $348.983^{*}$ & $376.289^{*}$ \\
Return & $(1.798)$ & $(1.925)$ \\
& 4.821 & 4.796 \\
ROA & $(1.258)$ & $(1.246)$ \\
& 9.734 & 10.205 \\
\$Annual Grants & $(1.219)$ & $(1.331)$ \\
& $0.005^{* * *}$ & \\
Annual Grant Delta & $(2.797)$ & $0.414^{* * *}$ \\
Constant & & $(2.908)$ \\
& & $-38.461^{* *}$ \\
Observations & $-39.655^{* *}$ & $(-2.233)$ \\
Pseudo ${ }^{2}$ & $(-2.299)$ & 510 \\
\hline
\end{tabular}

This table reports results from estimating Tobit regressions of \$Sensitivity on proxies for adverse selection problems and control variables. The model includes unreported year fixed effects. The full sample includes 510 new CEO announcements over the period 2004-2013, where new CEOs are externally hired, initial contracts are available through SEC filings, and the turnovers are not related to mergers and acquisitions. $\$$ Sensitivity is the sensitivity of the value of the inducement equity award portfolio to a one percent change in stock price, in thousands of dollars. Information Asymmetry is measured as the logarithm of (stock price volatility in event window [0,1], divided by stock price volatility on event day -1 ), where event day 0 is the announcement date and stock price is measured at five-minute intervals. IOS is the investment opportunity set estimated as the factor score of investment intensity, market-to-book assets, geometric mean annual growth rate of market value of assets, and R\&D expenditures scaled by assets (Baber et al. 1996). Industry Homogeneity is the industry average partial correlation coefficient, estimated using a two-factor regression model of monthly firm stock returns on an equal-weighted industry return index and an equal-weighted market index, averaged over the five years preceding the new CEO announcement (Parrino 1997). Size is the logarithm of book value of total assets, reported in millions of dollars. Leverage is the book value of debt divided by the market value of equity. Volatility is the daily stock return volatility for the year prior to the new CEO announcement Return is the buy-and-hold stock return over the 12 months prior to the new $\mathrm{CEO}$ announcement. ROA is the net income divided by the book value of total assets over the four quarters prior to the new CEO announcement. \$Annual Grants is the grant date fair value of total equity granted in the first year after the new CEO announcement, in thousands of dollars. Annual Grant Delta is the grant date sensitivity to one percent change in stock price of total equity granted in the first year after the new CEO announcement, in thousands of dollars. *, **, and *** indicate $p<0.10, p<0.05$, and $p<0.01$, based on one-tailed tests when there is a predicted sign, two-tailed otherwise. $t$-statistics are in parentheses 
the amount of cash sign-on bonuses as an additional explanatory variable and find, in untabulated results, that our conclusions are unchanged.

Annual equity grants designed to resolve moral hazard problems may also help to reduce adverse selection problems. To consider this, we examine how subsequent equity grants relate to $\$$ Sensitivity. ${ }^{20}$ We measure the grant date fair value and the sensitivity of the equity granted in the CEO's first year in office to a one percent change in stock price (delta). In many cases, the Summary Compensation and PlanBased Awards tables of the proxy statement combine the inducement equity grants with the other annual equity grants. To isolate and measure annual equity grants that are not part of the inducement equity grant, we collect annual equity grants from Form 4 filings for the newly hired CEO. We focus on Form 4 filings for the first 12 months following the new CEO announcement to reduce the influence of variation in employment time at the first fiscal year-end. ${ }^{21}$ In Table 7, we find positive and significant relations between \$Sensitivity and both the grant date fair value and delta of the annual equity grants. At the same time, we continue to find evidence in support of our hypotheses after controlling for other annual equity compensation measures.

If the CEO expects a positive reaction to the announcement, it is possible that firms with weaker governance structures compensate the executive with inducement grants that are more sensitive to the announcement return to enrich the CEO. We test this conjecture by examining the relation between $\$$ Sensitivity and board size and the proportion of the board that is independent. In untabulated results we find no evidence of a relation between these measures and \$Sensitivity.

\section{Conclusion}

We investigate how information asymmetry about the CEO influences contractual features. We focus on the sensitivity of inducement grants to the announcement of new CEOs. We predict and find that firms facing greater information asymmetry about the new CEO contract with inducement grants that are more sensitive to the announcement return. We also predict and find that firms with greater potential losses from underinvestment in risky projects and firms facing a higher cost of identifying and replacing a less productive CEO contract with inducement grants that are more sensitive to the announcement return. Consistent with CEOs accepting inducement grants that are more sensitive to the announcement return when they correctly expect the market to react favorably to their appointment, we find a positive relation between \$Sensitivity and the announcement return.

We consider whether factors that reduce information asymmetry relate to the sensitivity of the inducement grant to the new CEO announcement return. We find that

\footnotetext{
${ }^{20}$ Dutta (2008) suggests that the portfolio of CEO equity ownership may help resolve adverse selection problems related to CEO skill when both effort and skill affect the value of the equity holdings.

${ }^{21} \mathrm{We}$ find, in untabulated results, that the grant date fair value and delta of equity granted in the first year are $\$ 1,651,980$ and $\$ 21,330$, which are significantly less than the inducement grant magnitude and inducement grant sensitivity of $\$ 3,206,030$ and $\$ 33,450$, respectively.
} 
inducement grant sensitivity is negatively related to the use of a search firm and appointing an internal CEO. We find no evidence that boards allow CEOs to benefit from misrepresenting their type, nor that boards mitigate inducement grant risk by compensating the CEO for a negative CEO announcement reaction.

Taken together, our evidence supports our prediction that firms provide inducement grants that are more sensitive to the announcement return to help resolve adverse selection problems that result from information asymmetry about the new CEO. We shed new light on how boards of directors address one of the most important tasks they face: appointing a new CEO (Hermalin 2005; Adams et al. 2010). We contribute to understanding the use of compensation schemes to resolve adverse selection problems (Dutta 2008). Our findings are an important addition to prior literature that focuses on the magnitude of inducement grants to compensate the CEO for forgone wealth and the risk of the employer (e.g., Fee and Hadlock 2003; Xu and Yang 2016), and contribute to literature that investigates contracting to address uncertainty when hiring new CEOs (Darrough and Melumad 1995; Gillan et al. 2009; $\mathrm{Xu}$ and Yang 2016; Carter et al. 2019). Finally, our study is related to literature on contracting to resolve adverse selection problems in other settings (Houston and Ryngaert 1997; Cadman et al. 2014).

Acknowledgements We thank Peter Easton (editor) and the anonymous referees for their constructive comments on this paper. We thank workshop participants at Texas Tech University, the University of California Irvine, the University of Georgia, and the University of Nevada Las Vegas, and Lucile Faurel, Rachel Hayes, Xu Jiang, Yihui Pan, and Tjomme Rusticus for helpful comments. We also thank Shi Chen, Elia Ferracuti, Arthur Morris, and Jing Pan for research assistance.

Open Access This article is licensed under a Creative Commons Attribution 4.0 International License, which permits use, sharing, adaptation, distribution and reproduction in any medium or format, as long as you give appropriate credit to the original author(s) and the source, provide a link to the Creative Commons licence, and indicate if changes were made. The images or other third party material in this article are included in the article's Creative Commons licence, unless indicated otherwise in a credit line to the material. If material is not included in the article's Creatove Commons licence and your intended use is not permitted by statutory regulation or exceeds the permitted use, you will need to obtain permission directly from the copyright holder. To view a copy of this licence, visit http://creativecommons.org/licenses/by/4.0/

\section{Appendix A}

This appendix describes inducement equity grant types and sensitivity calculations, and presents a figure portraying how grants with specific features correspond to the various announcement return sensitivity categories.

The grant types (Categories) are as follows:

1. Pre Stock \#: 500 shares of stock granted two days prior to the CEO announcement;

2. Pre Stock \$: stock with a total value of $\$ 50,000$, granted two days prior to the CEO announcement;

3. Pre Option \#: 1,000 stock options granted two days prior to the CEO announcement;

4. Pre Option $\$$ : Stock options with a total value of $\$ 60,866.86$ granted two days prior to the CEO announcement;

5. Post Stock \#: 500 shares of stock granted at the end of the day following the CEO announcement;

6. Post Stock $\$$ : stock with a total value of $\$ 50,000$, granted at the end of the day following the CEO announcement;

7. Post Option \#: 1,000 stock options granted at the end of the day following the CEO announcement; 
8. Post Option $\$$ : stock options with a total value of $\$ 50,000$, granted at the end of the day following the CEO announcement.

To calculate the sensitivity to a one percent announcement return, \$Sensitivity Grant, assume that the stock price two days prior to the announcement is $\$ 100$ and the announcement return is one percent (\$1). Also assume that options are granted at the money and that the parameters to determine the stock option values include stock volatility of 0.3 , time to expiration of seven years, dividend yield of zero and a risk-free rate of $10 \%$. Also, assume the input parameters are constant across the new CEO announcement. With these assumptions, the sensitivity of each grant type to a one percent announcement return is as follows.

The one percent announcement return increases the value of Pre Stock \# from $\$ 50,000$ to $\$ 50,500$, resulting in a sensitivity of $\$ 500$.

Pre Stock \$ has the same sensitivity as Pre Stock \#, because the contracted value of shares equates to 1,000 shares. A one percent announcement return increases the value of Pre Stock $\$$ from $\$ 50,000$ to $\$ 50,500$, resulting in a sensitivity of $\$ 500$.

The value of Pre Option \#, which includes options granted prior to the new CEO announcement, is $\$ 60,866.86$. The sensitivity of the option value to a one percent change in stock price is one percent $* \$ 100$ (the stock price) $* .88309$ (the option delta) * 1,000 (the number of options), which is $\$ 883.09$.

Pre Option $\$$ includes options granted prior to the new CEO announcement. Based on the assumptions in this example, $\$ 60,866.86$ granted two days prior to the CEO announcement is equivalent to 1,000 options. The sensitivity of the option value to a one percent change in stock price is one percent $* \$ 100$ (the stock price) $* 0.88309$ (the option delta) $* 1,000$ (the number of options), which is $\$ 883.09$. Note that this is the same sensitivity as Pre Option \#.

Post Stock \# is sensitive to the announcement return because the number of shares is contracted prior to the announcement. The value of the 500 contracted shares increases by one percent, for a sensitivity of $\$ 500$. This example illustrates that despite granting the shares after the announcement, when the number of shares is contracted before the announcement the value of the shares is sensitive to the announcement return.

Post Stock $\$$ is unaffected by the CEO announcement return; the sensitivity of Post Stock $\$$ is zero. After the announcement, the firm issues 495.05 shares to meet the contracted $\$ 50,000$.

To estimate the sensitivity of Post Option \#, we first estimate the pre-announcement value of the options using the pre-announcement stock price and option pricing inputs. In this example, the Black-Scholes value is $\$ 60,866.86$ for the 1,000 stock options if granted prior to the new CEO announcement. An announcement return of one percent would cause the exercise price of the actual grant to increase by one percent, and assuming all other inputs remain constant, the Black-Scholes value of the 1,000 options granted after the announcement is $\$ 61,476.53$. Therefore, the sensitivity of Post Option \# to a one percent announcement return is the difference between the post-announcement value of $\$ 61,476.53$ and the pre-announcement value of $\$ 60,866.86$, which is $\$ 608.67$. 
Post Option $\$$ is unaffected by changes in stock price around the CEO announcement; therefore, the sensitivity of Post Option $\$$ is zero. After the announcement, the firm issues stock options to meet the contracted value of $\$ 50,000$.

\section{Appendix B: Variable definitions}

\$Sensitivity
Induce Equity Grants
Sign-on Cash Bonus
Information Asymmetry

Sensitivity of the value of the inducement equity award portfolio to a one percent change in stock price, reported in thousands of dollars.

Value of all inducement equity grants in thousands of dollars.

Sign-on cash bonus in thousands of dollars.

Logarithm of (stock price volatility in event window $[0,1]$, divided by stock price volatility on event day -1 ), where event day 0 is the announcement date and stock price is measured at five-minute intervals.

Industry Homogeneity Industry average partial correlation coefficient, estimated using a two-factor regression model of monthly firm stock returns on an equal-weighted industry return index and an equal-weighted market index, averaged over the five years preceding the new CEO announcement (Parrino 1997).

IOS

Investment opportunity set estimated as the factor score of investment intensity, market-to-book assets, geometric mean annual growth rate of market value of assets, and R\&D expenditures scaled by assets (Baber et al. 1996).

Size
Volatility

Return

$R O A$

$C A R[j, k]$

Ind. Adj. ROA

Ind. Adj. Return

Search Firm
Book value of total assets, reported in millions of dollars. Daily stock return volatility for the year prior to the new CEO announcement.

Buy-and-hold stock return over the 12 months prior to the new CEO announcement.

Net income divided by the book value of total assets over the four quarters prior to the new CEO announcement.

Abnormal return within the event window [j, $\mathrm{k}]$ using the market model, where the announcement date is day 0 and the market model is estimated with daily returns for the window [-160, -61].

Net income divided by the book value of total assets over the four quarters after the announcement date minus the industry average $R O A$ over the same period.

Buy-and-hold stock return over the 12 months after the new CEO announcement minus the industry average Return over the same period.

An indicator of using an executive search firm. 
\$Annual Grants

Annual Grant Delta

CEO Factor

Outside CEO

Board Overlap
Grant date fair value of total equity granted in the first year after the new CEO announcement, in thousands of dollars.

Grant date sensitivity to one percent change in stock price of total equity granted in the first year after the new CEO announcement, in thousands of dollars.

The principal component of prior CEO experience, which includes CEO age, being a CEO before, number of prior CEO positions, prior CEO tenure, number of industries with prior $\mathrm{CEO}$ experience, and prior $\mathrm{CEO}$ experience in the same industry as the hiring firm.

An indicator that equals 1 for outside CEO hires, and 0 otherwise.

An indicator for whether the incoming CEO and any board member previously served on the same board prior to the new CEO appointment or whether the incoming CEO worked at a firm where any board member of the hiring firm was employed or served as a board member

\section{References}

Aboody, D., \& Kasznik, R. (2000). CEO stock option awards and the timing of corporate voluntary disclosures. Journal of Accounting and Economics, 29(1), 73-100.

Adams, R.B., Hermalin, B.E., Weisbach, M.S. (2010). The role of boards of directors in corporate governance: a conceptual framework and survey. Journal of Economic Literature, 48(1), 58-107.

Altman, E.I. (1968). Financial ratios, discriminant analysis and the prediction of corporate bankruptcy. The Journal of Finance, 23(4), 589-609.

Ang, A., Hodrick, R.J., Xing, Y., Zhang, X. (2006). The cross-section of volatility and expected returns. The Journal of Finance, 61(1), 259-299.

Baber, W.R., Janakiraman, S.N., Kang, S.-H. (1996). Investment opportunities and the structure of executive compensation. Journal of Accounting and Economics, 21(3), 297-318.

Bharath, S.T., \& Shumway, T. (2008). Forecasting default with the Merton distance to default model. The Review of Financial Studies, 21(3), 1339-1369.

Bonnier, K.-A., \& Bruner, R.F. (1989). An analysis of stock price reaction to management change in distressed firms. Journal of Accounting and Economics, 11(1), 95-106.

Cadman, B., Carrizosa, R., Faurel, L. (2014). Economic determinants and information environment effects of earnouts: New insights from SFAS 141 (R). Journal of Accounting Research, 52(1), 37-74.

Carter, M.E., Franco, F., Tuna, A. (2019). Matching premiums in the executive labor market. The Accounting Review, Forthcoming. https://doi.org/10.2308/accr-52393.

Chang, W.-J., Hayes, R.M., Hillegeist, S.A. (2015). Financial distress risk and new CEO compensation. Management Science, 62(2), 479-501.

Clayton, M.C., Hartzell, J.C., Rosenberg, J. (2005). The impact of CEO turnover on equity volatility. The Journal of Business, 78(5), 1779-1808.

Coughlan, A.T., \& Schmidt, R.M. (1985). Executive compensation, management turnover, and firm performance: an empirical investigation. Journal of Accounting and Economics, 7(1-3), 43-66.

Darrough, M.N., \& Melumad, N.D. (1995). Divisional versus company-wide focus: the trade-off between allocation of managerial attention and screening of talent. Journal of Accounting Research, 33(Supplement), 65-94.

Dutta, S. (2008). Managerial expertise, private information, and pay-performance sensitivity. Management Science, 54(3), 429-442. 
Fee, C.E., \& Hadlock, C.J. (2003). Raids, rewards, and reputations in the market for managerial talent. Review of Financial Studies, 16(4), 1315-1357.

Gaver, J.J., \& Gaver, K.M. (1993). Additional evidence on the association between the investment opportunity set and corporate financing, dividend, and compensation policies. Journal of Accounting and Economics, 16(1-3), 125-160.

Gillan, S.L., Hartzell, J.C., Parrino, R. (2009). Explicit versus implicit contracts: evidence from CEO employment agreements. The Journal of Finance, 64(4), 1629-1655.

Greenwald, B.C. (1986). Adverse selection in the labour market. The Review of Economic Studies, 53(3), $325-347$.

Guay, W.R. (1999). The sensitivity of CEO wealth to equity risk: an analysis of the magnitude and determinants. Journal of Financial Economics, 53(1), 43-71.

Hermalin, B.E. (2005). Trends in corporate governance. The Journal of Finance, 60(5), 2351-2384.

Heron, R.A., \& Lie, E. (2007). Does backdating explain the stock price pattern around executive stock option grants? Journal of Financial Economics, 83(2), 271-295.

Houston, J.F., \& Ryngaert, M.D. (1997). Equity issuance and adverse selection: a direct test using conditional stock offers. The Journal of Finance, 52(1), 197-219.

Huson, M.R., Malatesta, P.H., Parrino, R. (2004). Managerial succession and firm performance. Journal of Financial Economics, 74(2), 237-275.

Institutional Shareholder Services (2016). U.S. equity compensation plans, frequently asked questions.

Jensen, M.C., \& Murphy, K.J. (1990). Performance pay and top-management incentives. Journal of Political Economy, 98(2), 225-264.

Kim, O., \& Verrecchia, R.E. (1997). Pre-announcement and event-period private information. Journal of Accounting and Economics, 24(3), 395-419.

Lambert, R., Leuz, C., Verrecchia, R.E. (2007). Accounting information, disclosure, and the cost of capital. Journal of Accounting Research, 45(2), 385-420.

Murphy, K.J. (1985). Corporate performance and managerial remuneration: an empirical analysis. Journal of Accounting and Economics, 7(1), 11-42.

Murphy, K.J., \& Zabojnik, J. (2004). CEO pay and appointments: a market-based explanation for recent trends. American Economic Review, 94(2), 192-196.

NASDAQ (2009). NASDAQ listing rule 5635(c). National Association of Securities Dealers Automated Quotations (NASDAQ).

Neuhierl, A., Scherbina, A., Schlusche, B. (2013). Market reaction to corporate press releases. Journal of Financial and Quantitative Analysis, 48(04), 1207-1240.

NYSE (2009). The New York stock exchange listed company manual 303A.08. NYSE.

Pan, Y., Wang, T.Y., Weisbach, M.S. (2015). Learning about ceo ability and stock return volatility. The Review of Financial Studies, 28(6), 1623-1666.

Parrino, R. (1997). CEO turnover and outside succession a cross-sectional analysis. Journal of Financial Economics, 46(2), 165-197.

Van Wesep, E.D. (2010). Pay (Be) for (e) performance: the signing bonus as an incentive device. Review of Financial Studies, 23(10), 3812-3848.

Warner, J.B., Watts, R.L., Wruck, K.H. (1988). Stock prices and top management changes. Journal of Financial Economics, 20, 461-492.

Weisbach, M.S. (1988). Outside directors and CEO turnover. Journal of Financial Economics, 20, 431460.

Xu, J., \& Yang, J. (2016). Golden hellos: signing bonuses for new top executives. Journal of Financial Economics, 122(1), 175-195.

Yermack, D. (1997). Good timing: CEO stock option awards and company news announcements. The Journal of Finance, 52(2), 449-476.

Publisher's note Springer Nature remains neutral with regard to jurisdictional claims in published maps and institutional affiliations. 